\title{
KETENGIKAN DAGING AYAM KAMPUNG UNGGUL SINJAI (AKUSI) YANG DIMARINASI MENGGUNAKAN BUBUK KULIT NANAS DENGAN WAKTU YANG BERBEDA
}

\section{The Meat Rancidity of Ayam Kampung Unggul Sinjai (AKUSI) Marinated Using Pineapple Skin Powder at Different Time}

\section{Azmi Mangalisu ${ }^{1}$ dan Armita Permatasari ${ }^{2}$}

${ }_{1}^{1}$ Program Studi Peternakan, Fakultas Sains dan Teknologi Universitas Muhammadiyah Sinjai 2Program Studi Manajemen Sumberdaya Perairan, Fakultas Sains dan Teknologi Universitas Muhammadiyah Sinjai

Email: azmimangalisu@gmail.com

\begin{abstract}
INTISARI
Ayam Kampung Unggul Sinjai (AKUSI) merupakan jenis ayam kampung yang apabila dipotong pada saat afkir memiliki daging yang alot dan mudah tengik. Proses marinasi menggunakan bubuk kulit nanas diharapkan mampu mengurangi ketengikan daging. Tujuan dari penelitian ini adalah melakukan proses marinasi menggunakan bubuk kulit nanas dengan waktu yang berbeda dan pengaruhnya terhadap ketengikan daging. Penelitian ini menggunakan Rancangan Acak Lengkap (RAL) pola faktorial dengan 2 faktor yaitu proses marinasi menggunakan bubuk kulit nanas dan waktu marinasi yang berbeda. Variabel yang diuji dalam penelitian ini yaitu nilai $\mathrm{pH}$ dan nilai TBA. Data yang diperoleh dianalisis sidik ragam dan diuji lanjut Beda Nyata Terkecil (BNT). Hasil penelitian menunjukkan bahwa ketengikan daging AKUSI afkir dapat diturunkan dengan cara marinasi menggunakan bubuk kulit buah nanas. Pemberian bubuk kulit buah nanas sebesar 15\% dengan lama waktu marinasi selama 90 menit merupakan marinasi terbaik untuk menurunkan nilai ketengikan daging.
\end{abstract}

Kata kunci: Daging, Marinasi, Nilai pH, TBA

\begin{abstract}
ABSTARCT
Ayam Kampung Unggul Sinjai (AKUSI) is a type of native chicken that is slaugthered when culled, has tough and easily rancid. The marination process using pineapple peel powder is expected to reduce meat rancidity. The purpose of this study was to carry out a marination process using pineapple peel powder at different times and its effect on meat rancidity. This study used a Completely Randomized Design (CRD) factorial pattern with 2 factors, namely the marination process using pineapple peel powder and different times. The variables tested in this study were the $\mathrm{pH}$ and TBA value. The data obtained were analyzed by analysis of variance and further tested the Least Significant Difference (LSD). The results showed that culled AKUSI rancidity could be reduced by marination process using pineapple peel powder. The provision of pineapple peel powder at 15\% with 90 minutes marination time was the best marination to reduce the meat rancidity.
\end{abstract}

Keywords: Meat, Marination, $p H$ Value, TBA

\section{PENDAHULUAN}

Daging merupakan salah satu komoditi peternakan untuk memenuhi kebutuhan protein hewani, karena daging mengandung protein yang bermutu tinggi sehingga sangat baik untuk menunjang pertumbuhan. Ayam
Kampung Unggul Sinjai (AKUSI) merupakan jenis ayam kampung petelur, namun daging ayam afkir mempunyai tekstur yang alot dan mengalami peningkatan oksidasi lemak yang tinggi sehingga daging mudah tengik. Untuk itu perlu adanya perlakuan khusus dalam penanganan setelah panen. Pemberian enzim 
bromelin pada daging merupakan teknik untuk mengempukan daging dan menghambat terjadinya oksidasi lemak. Enzim bromelin dapat diperoleh dari buah nanas.

Nanas mengandung gula, asam, asam askorbat, senyawa fenolik, mineral, dan enzim bromelin (Yahia, 2011). Enzim bromelin termasuk ke dalam golongan enzim protease yang mampu memecah protein rantai panjang menjadi fragmen protein yang lebih kecil bahkan sampai ke bentuk asam amino (Ali et al., 2015). Selama ini pemanfaatan buah nanas hanya pada daging buahnya saja, sementara kulitnya dibuang. Kulit buah nanas masih memiliki manfaat yaitu memiliki kandungan enzim bromelin yang cukup tinggi sehingga dapat membantu mengempukan daging AKUSI afkir yang alot dengan cara marinasi dengan waktu tertentu.

Proses pengempukan terjadi karena proteolisis pada berbagai fraksi protein daging oleh enzim. Semakin banyak terjadi proteolisis pada miofibril, maka semakin banyak protein terlarut. Bromelin tergolong kelompok enzim protease sulfhidril (Chairunisa, 1985). Bromelin memiliki kemampuan untuk memecah struktur molekul protein menjadi bentuk lebih sederhana (asam amino) (Suprapti, 2008). Kecepatan katalisis akan semakin meningkat dengan meningkatnya konsentrasi enzim. Tingginya konsentrasi enzim, akan mempengaruhi banyaknya substrat yang ditransformasi. Lamanya waktu kerja enzim juga mempengaruhi keaktifannya. Kecepatan katalis enzim akan meningkat dengan lamanya waktu reaksi (Ferdiansyah, 2005).

Pemberian kulit buah nanas diharapkan mampu meningkatkan kualitas produk ternak melalui penghambatan proses oksidasi lemak yang terdapat di dalamnya, sehingga perlu dilakukan penelitian mengenai pengaruh pemberian kulit buah nanas sebagai bahan marinasi daging AKUSI. Kulit buah nanas pada penelitian ini diberikan dalam bentuk bubuk untuk mengoptimalkan nilai $\mathrm{pH}$ dan nilai Thiobarbituric acid (TBA) dalam penghambatan proses oksidasi lemak. Tujuan dari penelitian ini adalah untuk mengetahui efektivitas marinasi bubuk kulit buah nanas dengan lama waktu yang berbeda terhadap tingkat ketengikan daging.

\section{METODE}

\section{Materi Penelitian}

Bahan yang digunakan dalam penelitian ini yaitu daging ayam AKUSI afkir bagian dada, bubuk kulit buah nanas, akuades, asam klorida, asam asetat, bubuk TBA, larutan buffer $\mathrm{pH} 4$ dan $\mathrm{pH}$ 7. Peralatan yang digunakan dalam penelitian ini adalah pengaduk, timbangan analitik, blender, labu destilasi, alat destilasi, tabung reaksi, rak tabung, magnetic stirrer, erlenmeyer, $\mathrm{pH}$ meter, micro pipet, tip, waterbath, dan spektrofotometer UV-VIS.

\section{Rancangan Penelitian}

Penelitian ini dilakukan secara eksperimental menggunakan rancangan acak lengkap (RAL) pola faktorial dengan 2 faktor perlakuan. Faktor A adalah perlakuan level bubuk kulit nanas meliputi A1 (bubuk kulit nanas 0\%), A2 (bubuk kulit nanas 5\%), A3 (bubuk kulit nanas 10\%), A4 (bubuk kulit nanas 15\%), dan A5 (bubuk kulit nanas 20\%) dihitung dari bobot daging. Faktor B adalah perlakuan lama waktu marinasi meliputi B1 (30 menit), B2 (60 menit), B3 (90 menit), dan B4 (120 menit). Setiap perlakuan terdiri dari 3 ulangan.

\section{Prosedur Penelitian}

Pembuatan bubuk kulit nanas: Kulit buah nanas segar dibersihkan kemudian dikeringkan menggunakan oven vakum pada suhu $50^{\circ} \mathrm{C}$ selama 24 jam. Selanjutnya, kulit buah nanas yang telah kering kemudian dihaluskan dengan blender. Bubuk kulit buah nanas kemudian digunakan dalam proses marinasi.

Preparasi sampel: Sampel daging AKUSI afkir dibersihkan dari kotoran. Sampel ditimbang masing-masing sebanyak $200 \mathrm{~g}$ dan 
dimasukkan ke dalam plastik klip. Masingmasing sampel ditambahkan bubuk kulit buah nanas sesuai dengan perlakuan dan disimpan pada suhu ruang sesuai dengan lama waktu marinasi yang telah ditentukan.

\section{Parameter yang diukur}

Nilai pH. Alat $\mathrm{pH}$ meter dinyalakan dan dinetralkan selama 15 sampai 30 menit dan distandarisasi dengan larutan buffer $\mathrm{pH} 4$ dan $\mathrm{pH}$ 7. Elektroda $\mathrm{pH}$ meter kemudian dibilas dengan akuades lalu dikeringkan dengan kertas tisu. Sampel diukur setelah $\mathrm{pH}$ meter dikalibrasi. Alat $\mathrm{pH}$ meter dicelup pada sampel lalu dibiarkan sampai angka $\mathrm{pH}$ meter stabil. Nilai yang tertera pada layar monitor pH meter kemudian dicatat. Setelah dilakukan pengukuran, $\mathrm{pH}$ meter kemudian dibilas dengan akuades dan dikeringkan dengan tisu.

Nilai TBA. Penentuan nilai TBA dilakukan dengan cara sampel ditimbang sebanyak $10 \mathrm{mg}$ ditambahkan $50 \mathrm{ml}$ akuades kemudian dihancurkan selama 2 menit. Larutan sampel ditambahkan asam klorida 2,5 $\mathrm{ml}$ dan 47,5 ml akuades, selanjutnya dipindah ke dalam labu destilasi. Labu destilat dipasang pada alat destilasi. Destilasi dijalankan dengan pemanasan 300 sampai 600 watt sehingga diperoleh destilat sebanyak $50 \mathrm{ml}$ dengan lama pemanasan 10 menit. Destilat yang diperoleh dipindahkan ke dalam tabung reaksi dan ditambahkan reagen TBA sebanyak $5 \mathrm{ml}$ (larutan 0,02 M TBA dalam 90\% asam asetat glasial). Larutan dicampur dalam tabung reaksi tertutup dan dimasukkan ke dalam air panas $75^{\circ} \mathrm{C}$ selama 35 menit. Tabung reaksi didinginkan dengan air mengalir kemudian diukur pada panjang gelombang $528 \mathrm{~nm}$ dengan larutan blanko sebagai titik nol. Nilai TBA dihitung dan dinyatakan dalam mg malonaldehid/kg sampel.

\section{Analisis Data}

Data yang diperoleh dianalisis sidik ragam berdasarkan Rancangan Acak Lengkap (RAL) pola faktorial dengan 2 faktor perlakuan dan 3 ulangan. Apabila data perlakuan menunjukkan pengaruh nyata maka dilakukan uji lanjut Beda Nyata Terkecil (BNT) (Gomes dan Gomez, 2010).

\section{HASIL DAN PEMBAHASAN}

\section{Nilai pH}

Nilai $\mathrm{pH}$ dipengaruhi adanya ion $\mathrm{H}^{+}$. Semakin banyak asam laktat yang dihasilkan maka konsentrasi ion $\mathrm{H}^{+}$semakin meningkat dan terukur sebagai pH (Nisa et al., 2008). Hasil penelitian mengenai nilai $\mathrm{pH}$ daging AKUSI dengan marinasi bubuk kulit buah nanas (Ananas comosus L. Merr) disajikan pada Tabel 1.

Tabel 1. Rata-rata Nilai pH Daging AKUSI dengan Marinasi Kulit Buah Nanas dengan Lama Waktu yang Berbeda

\begin{tabular}{cccccc}
\hline \multirow{2}{*}{$\begin{array}{c}\text { Level Bubuk } \\
\text { Kulit Buah Nanas } \\
(\%)\end{array}$} & 30 & 60 & 90 & 120 & Rata-Rata \\
\cline { 2 - 5 } & & $6,77 \pm 0,06$ & $6,36 \pm 0,09$ & $6,75 \pm 0,19$ & $6,56 \pm 0,09^{\mathrm{c}}$ \\
\hline 0 & $5,99 \pm 0,15$ & $6,66 \pm 0,01$ & $5,82 \pm 0,19$ & $6,56 \pm 0,16$ & $6,26 \pm 0,13^{\mathrm{a}}$ \\
10 & $6,04 \pm 0,49$ & $6,72 \pm 0,03$ & $6,57 \pm 0,05$ & $6,45 \pm 0,18$ & $6,44 \pm 0,19 \mathrm{bc}$ \\
15 & $5,79 \pm 0,04$ & $6,71 \pm 0,18$ & $6,50 \pm 0,03$ & $6,51 \pm 0,06$ & $6,37 \pm 0,08^{\mathrm{ab}}$ \\
20 & $5,89 \pm 0,14$ & $6,70 \pm 0,13$ & $6,31 \pm 0,09$ & $6,48 \pm 0,06$ & $6,34 \pm 0,11^{\mathrm{ab}}$ \\
\hline Rata-rata & $6,01 \pm 0,17 \mathrm{a}$ & $6,71 \pm 0,08^{\mathrm{d}}$ & $6,31 \pm 0,09 \mathrm{~b}$ & $6,55 \pm 0,13^{\mathrm{c}}$ & \\
\hline
\end{tabular}

abcd Superskrip yang berbeda pada baris atau kolom yang sama menunjukkan perbedaan sangat nyata $(\mathrm{P}<0.01)$

Hasil penelitian menunjukkan bahwa pemberian bubuk kulit buah nanas dan lama waktu marinasi yang berbeda berpengaruh sangat nyata $(\mathrm{P}<0,01)$ terhadap nilai $\mathrm{pH}$ pada daging AKUSI dan ada interaksi antara keduanya. Hasil uji lanjut Least Significance 
Different (LSD) menunjukkan nilai $\mathrm{pH}$ yang berbeda nyata $(\mathrm{P}<0,05)$ meningkat lalu menurun lagi sejalan dengan bertambahnya pemberian bubuk kulit buah nanas dan lama waktu marinasi dan optimal pada level 15\% selama 90 menit.

Ketidakstabilan nilai pH dipengaruhi oleh enzim yang aktif pada bubuk kulit buah nanas yang tidak sesuai dengan level yang ada, sehingga proses metabolisme yang terjadi mengakibatkan keanekaragaman nilai $\mathrm{pH}$. Kondisi asam dihasilkan dari proses perombakan nutrisi dari daging AKUSI afkir. Adanya perombakan nutrisi yang rendah menyebabkan hasil metabolit berupa asam yang dihasilkan dari perombakan karbohidrat, protein dan rendah lemak menjadi akumulasi asam rendah sehingga nilai $\mathrm{pH}$ daging menjadi tinggi.

Radamayanti (2001) menyatakan bahwa ketersediaan nutrisi dalam medium akan mengalami peningkatan keasaman akibat adanya konsentrasi ion hidrogen untuk pembentukan energi dan komponenkomponen sel. Pertumbuhan sel diiringi dengan terbentuknya metabolit berupa asam laktat yang dihasilkan dari perombakan gula, protein, dan asam-asam lainnya. Mangalisu dan Permatasari (2019) menyatakan bahwa enzim bromelin berperan sebagai biokatalisator yang mempercepat reaksi pemecahan protein menjadi asam amino. Semakin tinggi konsentrasi enzim yang ditambahkan, maka kecepatan reaksi akan semakin tinggi sehingga semakin banyak ikatan peptida yang terhidrolisis, akibatnya semakin banyak pula protein yang terhidrolisis menjadi asam amino.

Perlakuan waktu marinasi yang berbeda pada daging AKUSI afkir menunjukkan adanya ketidakstabilan nilai $\mathrm{pH}$ sejalan dengan bertambahnya lama waktu marinasi. Hal ini terjadi karena perbedaan waktu aktifnya enzim bromelin pada bubuk kulit buah nanas. Hal ini mengakibatkan proses metabolisme enzim bromelin yang menghasilkan asam laktat terjadi pada waktu yang berbeda.
Akibatnya penurunan nilai $\mathrm{pH}$ yang terjadi diperoleh mempunyai waktu yang berbeda pula. Hal ini sesuai dengan pendapat Moldovan et al. (2012) bahwa nilai pH yang terukur bergantung pada kondisi asam yang dihasilkan dari perombakan nutrisi pada daging AKUSI afkir.

Kondisi asam akan mengurangi degradasi sifat-sifat asam organik. Pokorny et al. (2001) menyatakan semakin rendah $\mathrm{pH}$ ekstrak berarti dalam ekstrak tersebut semakin banyak $\mathrm{H}^{+}$bebas, $\mathrm{H}^{+}$ini dapat meregenerasi senyawa antioksidan dengan cara berikatan dengan radikal fenoksi membentuk senyawa antioksidan kembali.

\section{Nilai TBA}

Uji TBA adalah suatu uji untuk mengukur tingkat oksidasi lemak berbagai bahan. Semakin tinggi nilai TBA maka semakin tinggi pula ketengikan atau proses oksidasi yang terjadi (Ketaren, 1986). Hasil penelitian mengenai nilai TBA daging AKUSI afkir dengan marinasi bubuk kulit buah nanas disajikan pada Tabel 2 .

Hasil penelitian menunjukkan bahwa pemberian bubuk kulit buah nanas dan lama waktu yang berbeda berpengaruh sangat nyata $(\mathrm{P}<0,01)$ terhadap nilai TBA daging AKUSI afkir dan ada interaksi antara keduanya. Nilai TBA pada perlakuan kontrol lebih tinggi jika dibandingkan dengan sampel yang ditambahkan bubuk kulit buah nanas. Hal tersebut terjadi karena adanya kemampuan enzim bromelin menghasilkan antioksidan yang dapat menghambat terjadinya oksidasi lemak. Menurut Winarsi (2007) antioksidan yang dihasilkan enzim bromelin merupakan antioksidan enzimatis yang bekerja dengan cara mencegah terbentuknya senyawa radikal bebas.

Suratmo (2009) menyatakan bahwa antioksidan mampu memperlambat atau mencegah oksidasi dimana radikal bebas cenderung akan bereaksi dengan antioksidan daripada dengan molekul lainnya. Menurut Kusumaningtyas et al. (2015) komponen 
peptida dan asam amino yang terbentuk dari pemecahan protein dapat bertindak sebagai antioksidan.

Tabel 2. menunjukkan ketengikan pada daging AKUSI afkir berbeda nyata pada perlakuan lama waktu marinasi yang berbeda. Tingkat ketengikan optimum pada waktu marinasi selama 90 menit. Aktivitas antioksidan dapat terjadi karena adanya aktivitas enzim bromelin. Enzim bromelin membutuhkan waktu yang relatif singkat dalam merombak protein pada daging AKUSI afkir menjadi senyawa-senyawa yang lebih sederhana seperti asam-asam dan gugus peptida yang memiliki sifat antioksidan (Mangalisu dan Permatasari, 2019).

Tabel 2. Rata-rata Nilai TBA Daging AKUSI afkir dengan Marinasi Bubuk Kulit Buah Nanas dengan Lama Waktu yang Berbeda

\begin{tabular}{cccccc}
\hline Level Bubuk & \multicolumn{4}{c}{ Waktu Marinasi (menit) } & \multirow{2}{*}{ Rata-Rata } \\
\cline { 2 - 5 } Kulit Nanas (\%) & 30 & 60 & 90 & 120 & \\
\hline 0 & $4,521 \pm 0,15$ & $2,087 \pm 0,10$ & $2,451 \pm 0,60$ & $3,062 \pm 0,36$ & $3,030 \pm 0,30^{\mathrm{c}}$ \\
5 & $3,485 \pm 0,23$ & $1,377 \pm 0,23$ & $0,588 \pm 0,60$ & $2.126 \pm 0,15$ & $1,894 \pm 0,17^{\mathrm{a}}$ \\
10 & $3,699 \pm 0,23$ & $3,001 \pm 0,13$ & $1,086 \pm 0,42$ & $2,807 \pm 0,35$ & $2,648 \pm 0,28^{\mathrm{b}}$ \\
15 & $4,775 \pm 0,01$ & $1,628 \pm 0,32$ & $1,057 \pm 0,24$ & $2,445 \pm 0,19$ & $2,476 \pm 0,19^{\mathrm{b}}$ \\
20 & $2,677 \pm 0,07$ & $3,618 \pm 0,08$ & $1,499 \pm 0,62$ & $2,898 \pm 0,06$ & $2,673 \pm 0,21^{\mathrm{b}}$ \\
\hline Rata-rata & $3,831 \pm 0,14^{\mathrm{d}}$ & $2,342 \pm 0,17^{\mathrm{b}}$ & $1,336 \pm 0,39^{\mathrm{a}}$ & $2,667 \pm 0,22^{\mathrm{c}}$ & \\
\hline
\end{tabular}

abcd Superskrip yang berbeda pada baris atau kolom yang sama menunjukkan perbedaan sangat nyata $(\mathrm{P}<0.01)$

Nilai TBA tertinggi terdapat pada daging AKUSI afkir dengan waktu marinasi 0 menit sedangkan nilai TBA terendah terdapat pada daging AKUSI afkir dengan waktu marinasi 90 menit. Hal tersebut terjadi karena kerusakan asam lemak tak jenuh sehingga menyebabkan ketengikan. Kondisi tersebut ditandai dengan meningkatnya jumlah bilangan TBA selama marinasi, namun dengan penambahan bubuk kulit nanas yang mengandung enzim bromelin dapat menghasilkan senyawa antioksidan mampu menurunkan bilangan TBA selama waktu marinasi.

Winarno dan Fernandez (2007) reaksi oksidasi dimulai dengan pembentukan radikal bebas asam lemak. Radikal ini dengan oksigen membentuk peroksida aktif yang membentuk hidroperoksida yang bersifat tidak stabil yang menimbulkan ketengikan pada produk. Pereira et al. (2009) menyatakan bahwa kerusakan asam lemak tak jenuh selama marinasi akan menyebabkan ketengikan yang ditandai dengan meningkatnya jumlah bilangan TBA selama marinasi. Penambahan bahan sumber antioksidan mampu menurunkan bilangan TBA.

\section{KESIMPULAN}

Ketengikan daging AKUSI afkir dapat diturunkan dengan cara marinasi menggunakan bubuk kulit buah nanas. Pemberian bubuk kulit buah nanas sebesar $15 \%$ dengan lama waktu marinasi selama 90 menit merupakan marinasi terbaik untuk menurunkan nilai ketengikan daging.

\section{UCAPAN TERIMA KASIH}

Penelitian ini merupakan bagian dari Penelitian Dosen Pemula DRPM KEMENRISTEKDIKTI Tahun 2019, sehingga kami ucapkan terima kasih kepada KEMENRISTEKDIKTI atas bantuan dananya sehingga penelitian ini terlaksana. Kami juga mengucapkan kepada Kepala Laboratorium Teknologi Hasil Ternak, Universitas Hasanuddin dan atas bantuan Himpunan Mahasiswa Teknologi Hasil Ternak.

\section{DAFTAR PUSTAKA}

Ali, A.A., M.A. Milala, and I.A. Gulani. 2015. Antimicrobial effect of crude bromelain 
extracted from pineapple fruit. Advances in Biochemistry. 3(1):1-4.

Chairunnisa. 1985. Hidrolisis kasein oleh enzim bromelin kasar dari bonggol nanas. Tesis. Universitas Gadjah Mada. Yogyakarta.

Ferdiansyah, V. 2005. Pemanfaatan Kitosan dari Cangkang Udang Sebagai Matriks Penyangga pada Imobilisasi Enzim Protease. Skripsi. Institut Pertanian Bogor. Bogor.

Gomes, K.A. dan A.A. Gomez. 2010. Statistical Procedures for Agricultural Research (Prosedur Statistik Untuk Penelitian Pertanian. Alih Bahasa Oleh E. Syamsuddin dan J.S. Baharsyah). Edisi Kedua. UI Press. Jakarta.

Ketaren, S. 1986. Pengantar Teknologi Minyak dan Lemak Pangan. Cetakan Pertama. UI-Press. Jakarta.

Kusumaningtyas, E., R. Widiastuti, H.D. Kusumaningrum, dan M.T. Suhartono, 2015. Aktivitas antibakteri dan antioksidan hidrolisat hasil hidrolisis protein susu kambing dengan ekstrak kasar bromelin. Jurnal Teknologi dan Industri Pangan. 26(2):179-188.

Mangalisu, A. dan A. Permatasari. 2019. Optimalisasi antioksidan daging ayam kampung unggul sinjai (AKUSI) dengan marinasi bubuk kulit nanas (Anannas comosus L. Merr). Agrovital Jurnal Ilmu Pertanian. 4(2):81-87.

Moldovan, B., L. David, C. Chişbora, and C.C. Cimpoiu. 2012. degradation kinetics of anthocyanins from European cranberrybush (Viburnum opulus L.) fruit extracts. Effects of temperature, ph and storage solvent. Molecules. 17:11655-11666.

Nisa, F.C., J. Kusnadi, dan R. Chrisnasari. 2008. Viabilitas dan deteksi subletal bakteri probiotik pada susu kedelai fermentasi instan metode pengeringan beku (kajian jenis isolate dan konsentrasi sukrosa sebagai krioprotektan). Jurnal Teknologi Pertanian. 9(1):40-51.

Pereira, A.L.F., T.F. Vidal, M.C. Teixeira, P.F. Oliveira, R.C.F. Pompeu, M.M.M. Vieira, and J.F.F. Zapata. 2009. Antioxidant effect of mango seed extract and butylated hydroxytoluene in bologna- type mortadella during storage. Science Technology. 31(1):35-40.

Pokorny, J., N. Yanishlieva, dan M. Gordon. 2001. Antioxidant in Food. CRC Press Cambridge. England.

Radamayanti, E. 2001. Pembuatan Yoghurt Susu Tempe; Kajian Penambahan Susu Skim dan Air Pengekstrak Tempe Terhadadap Sifat Fisik, Kimia, Fisika, dan Organoleptik. Skripsi. Universitas Brawijaya Malang. Malang.

Suprapti, L.M. 2002. Pengawetan Telur, Telur Asin Tepung Telur, dan Telur Beku. Kanisius. Yogyakarta.

Suprapti. 2008. Uji protein dan lemak pada telur asin hasil pengasinan dengan abu pelepah kelapa. Tesis. Universitas Muhammadiyah Surakarta. Surakarta.

Suratmo. 2009. Potensi ekstrak daun sirih merah (Piper crocatum) sebagai antioksidan. Prosiding. Basics Science Seminar Universitas Brawijaya. Malang.

Winarno, F.G. dan E.I. Fernandez. 2007. Susu dan Produk Fermentasinya. Mbrio Press. Jakarta.

Winarsi, H. 2007. Antioksidan Alami dan Radikal Bebas. Penerbit Kanisius. Yogyakarta.

Yahia, M.E. 2011. Postharvest Biology and Technology of Tropical and Subtropical Fruits. Woodhead Publishing Limited. Cambridge. 